\section{Design of an Internal DNA Standard for Com- petitive RT-PCR Using Partial Intron Sequence and an Artificial Linker Sequence}

\section{BioTechniques 31:730-734 (October 2001)}

Competitive (quantitative) RT-PCR analysis is a method for determining the amount of a specific mRNA/cDNA transcript in a sample. For this purpose, an internal DNA or RNA standard must be included in the reaction. The standard is amplified with the same rate as the natural transcripts. Thereby, it is possible to determine the amount of mRNA/cDNA transcripts in a sample by comparing the signal intensity from a known amount of added standard to the signal intensity from the sample transcripts. To distinguish between the products of the sample transcripts and the standard, a number of nucleotides can be added to the standard to permit the separation of the standard from the sample transcripts by length (by gel electrophoresis). To ensure equal amplification rates of the standard and the natural transcript, the standard should be as similar to the natural transcript as possible. Therefore, the standard usually includes the complete target sequence or a part of it. Insertion of additional nucleotides in the standard can be achieved by including an artificial sequence or an intron (1). To ensure adequate separation by gel electrophoresis while maintaining similar amplification rates, the insertion must be of a certain length, depending on the length of the products to be separated. Sometimes the optimal insert length is not compatible with the inclusion of a full-length intron or a short linker sequence. In these cases, the alternative of designing and adding an appropriate artificial sequence as an insertion instead can be both cumbersome and relatively expensive.

Therefore, we have modified the method of Diviacco et al. (1) by combining the two approaches to achieve the insertion of a partial intron sequence in addition to a short artificial linker sequence into the standard DNA sequence by a combination of two separate PCRs. The following describes, as an example, the design of an internal DNA standard for $\gamma$-globin transcripts, which has been used for analyzing $\gamma$-globin gene expression in nucleated erythrocytes (2). The method is shown schematically in Figure 1. One reaction (A) is set up using genomic DNA as template for primers targeting the $5^{\prime}$ end of exon 1 and a sequence in intron 1 . This reaction amplifies exon 1 and 50 bases of intron 1. In the other reaction $(\mathrm{B}), \mathrm{cDNA}$ (which contains no introns) serves as a template for primers targeting the $5^{\prime}$ end of exon 2 and the $3^{\prime}$ untranslated region (3' UTR) of the gene. This reaction amplifies exon 2, exon 3, and the 3' UTR. The inclusion of the $3^{\prime}$ UTR of the gene facilitates the potential use of the resulting standard for in vitro transcription and re- verse transcription, if one should later wish to create an RNA standard (although this was not included in the present study). The $3^{\prime}$ end of the primer for intron 1 contains an artificial linker sequence that is different from any genomic sequence and complementary to a linker sequence in the $5^{\prime}$ end of the primer for exon 2. When the denatured PCR products from reactions $\mathrm{A}$ and $\mathrm{B}$ are mixed together, the linker sequences will anneal to each other during renaturation. Primers targeting exon 1 and exon 3 are added, and only properly linked sequences containing the sequences of exon 1 and 3 in the correct orientation will be amplified in the subsequent PCR. The product of this reaction will be the DNA standard containing the sample $\gamma$-globin sequence and part of the intron sequence and the arti-

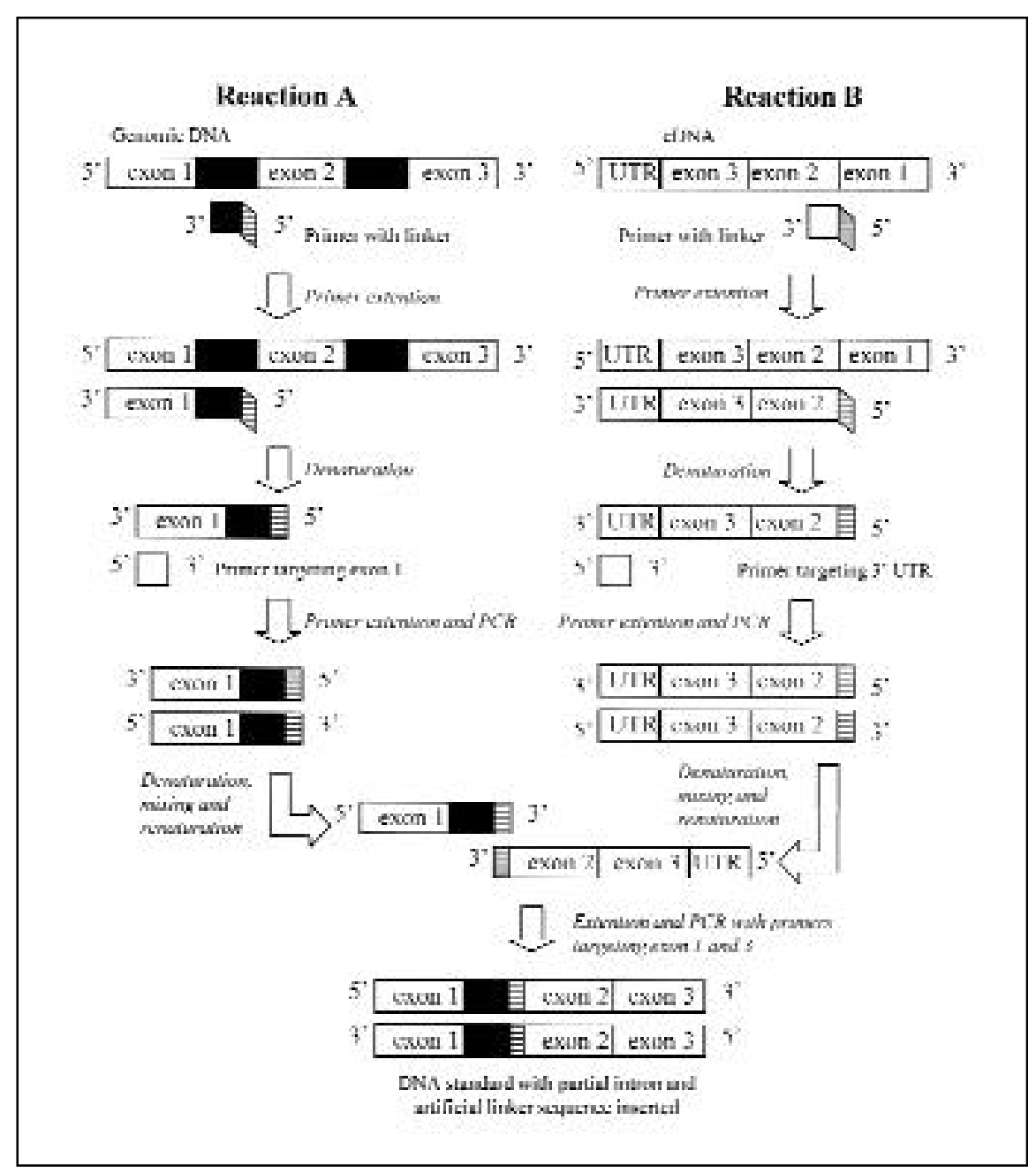

Figure 1. Schematic drawing of general principle of designing an internal DNA (or RNA) standard for competitive RT-PCR with the use of a partial intron sequence and an artificial linker sequence. 
ficial linker sequence. The following protocol describes the generation of such a DNA standard using the $\gamma$-globin sequence as an example. The reaction conditions for reactions $\mathrm{A}$ and $\mathrm{B}$ were similar: $5.0 \mu \mathrm{L} \mathrm{MgCl}_{2}(25 \mathrm{mM})(\mathrm{MBI}$ Fermentas, Vilnius, Lithuania), 5.0 $\mu \mathrm{L}$ 10× PCR buffer (MBI Fermentas), 1.0 $\mu \mathrm{L}$ Taq DNA polymerase $(1 \mathrm{U} / \mu \mathrm{L})$ (MBI Fermentas), $5.0 \mu \mathrm{L}$ dNTP $(4 \times 2$ $\mathrm{mM}), 7.5 \mu \mathrm{L}$ gene-specific primer $(10$ $\mu \mathrm{M})$ (TAGC, Copenhagen, Denmark), $2.5 \mu \mathrm{L}$ linker primer $(10 \mu \mathrm{M})$ (TAGC). Template for reaction A: $2.0 \mu \mathrm{L}$ human genomic DNA (100 ng/ $\mu \mathrm{L})$. Template for reaction B: $1.0 \mu \mathrm{L}$ K562 cDNA, reverse transcribed using an oligo-dT

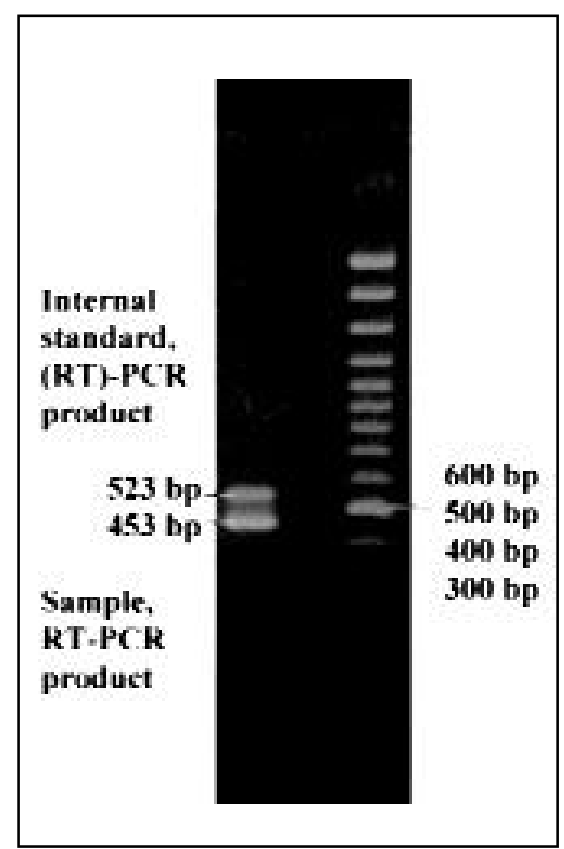

Figure 2. Separation of standard and sample RT-PCR products by gel electrophoresis. An internal competitive $\gamma$-globin DNA standard of 523 bp was obtained with the intron-linker method as described in the text. The internal standard is $70 \mathrm{bp}$ longer than the sample $\gamma$-globin RTPCR product $(453 \mathrm{bp})$. Fixed concentrations of sample cDNA are mixed with different amounts of internal DNA standard and co-amplified. The amount of RT-PCR products is then quantified by densitometric scanning (but can also be determined by using a fluorochrome-conjugated primer, followed by analysis in automated DNA sequencing instruments). The amount of sample cDNA/mRNA is determined from a plot of the $\log$ of the amount of internal standard added to the sample before PCR against the log of the internal standard:sample ratios obtained after RTPCR (the amount of added internal standard that results in a 1:1 ratio of sample to standard RTPCR products corresponds to the amount of natural transcript cDNA/mRNA in the sample). primer. For both reactions: nuclease-free water (Promega, Madison, WI, USA) up to a volume of $50 \mu \mathrm{L}$. Thermocycling conditions were $94^{\circ} \mathrm{C}$ for $3 \mathrm{~min} ; 2 \mathrm{cy}$ cles of $94^{\circ} \mathrm{C}$ for $1 \mathrm{~min}, 50^{\circ} \mathrm{C}$ for $1 \mathrm{~min}$, and $72^{\circ} \mathrm{C}$ for $1 \mathrm{~min} ; 33$ cycles of $94^{\circ} \mathrm{C}$ for $1 \mathrm{~min}, 65^{\circ} \mathrm{C}$ for $1 \mathrm{~min}$, and $72^{\circ} \mathrm{C}$ for $1 \mathrm{~min}$, followed by $72^{\circ} \mathrm{C}$ for $5 \mathrm{~min}$, hold at $4^{\circ} \mathrm{C}$. Gene-specific primers: exon-targeting primer A, 5' -ACGCCATGGGTCATTTCACAGA-3'; UTR-targeting primer B, 5-TTTTTTTTTTTTTTTTTTTTATTTATTATTTGTATTGCTTGC-3'. Linker primers: linker primer A, 5'-ACCTGCAGGGATCCGTCGACCAGGCACAGGGTCCTTCCTT-3'; linker primer B, 5-GTCGACGGATCCCTGCAGGTGCTCCTGGTTGTCTACCCATG-3'. If other primers are used, the annealing temperature for the last 33 cycles should be adjusted correspondingly. The bold letters in the primer sequences constitute the artificial linker sequence, which must be included in the primers. The PCR products were analyzed on a $1 \%$ agarose gel. Pipet tips were dipped in each product band resulting from the reactions $\mathrm{A}$ and $\mathrm{B}$, and the tips were then incubated together in $50 \mu \mathrm{L}$ sterile water for $2 \mathrm{~min}$ at room temperature. Five microliters of this mixture were used as template with the following PCR mixture: $10.0 \mu \mathrm{L}$ $\mathrm{MgCl}_{2}(25 \mathrm{mM}), 10.0 \mu \mathrm{L} 10 \times \mathrm{PCR}$ buffer, $2.0 \mu \mathrm{L} \mathrm{Taq}$ DNA polymerase (1 $\mathrm{U} / \mu \mathrm{L}), 10.0 \mu \mathrm{L}$ dNTP $(4 \times 2 \mathrm{mM}), 5.0$ $\mu \mathrm{L}$ exon-targeting primer $\mathrm{A}(10 \mu \mathrm{M})$, $5.0 \mu \mathrm{L}$ exon-targeting primer $\mathrm{B}(10$ $\mu \mathrm{M})$, and nuclease-free water up to a volume of $100 \mu \mathrm{L}$. Thermocycling conditions were $94^{\circ} \mathrm{C}$ for $1 \mathrm{~min}, 90^{\circ} \mathrm{C}$ for 1 $\min , 85^{\circ} \mathrm{C}$ for $1 \mathrm{~min}, 80^{\circ} \mathrm{C}$ for $1 \mathrm{~min}$, $75^{\circ} \mathrm{C}$ for $1 \mathrm{~min}, 65^{\circ} \mathrm{C}$ for $1 \mathrm{~min}, 60^{\circ} \mathrm{C}$ for $1 \mathrm{~min}, 55^{\circ} \mathrm{C}$ for $1 \mathrm{~min}, 50^{\circ} \mathrm{C}$ for 2 $\mathrm{min}$, and $72^{\circ} \mathrm{C}$ for $1 \mathrm{~min} ; 30$ cycles of $94^{\circ} \mathrm{C}$ for $1 \mathrm{~min}, 60^{\circ} \mathrm{C}$ for $1 \mathrm{~min}$, and $72^{\circ} \mathrm{C}$ for $1 \mathrm{~min}$, followed by $72^{\circ} \mathrm{C}$ for 5 min. Exon-targeting primer B: 5'-GAGCTCAGTGGTATCTGGAGGA-3'. The PCR product was analyzed by gel electrophoresis on a $1 \%$ agarose gel. After preparation of the PCR product, it was cloned using the TOPO ${ }^{\circledR}$ TA Cloning Kit with pCR-2.1 vector (Invitrogen, Groeningen, The Netherlands) according to the manufacturer's instructions. The plasmid carrying the standard sequence was diluted 1:5000, and from this template the DNA standard was am - plified in a PCR as described above. The PCR product was purified by spin column technique using Sephacryl ${ }^{\mathrm{TM}}$ S-400 HR (Amersham Pharmacia Biotech, Uppsala, Sweden) and quantified by absorbance measurements. The PCR product was hereafter used as a DNA standard (see Figure 2 for further details).

To test the kinetics of co-amplification of the internal competitive $\gamma$-globin DNA standard and sample cDNA, approximately equal amounts of DNA standard and cDNA were co-amplified over a range of PCR amplification cycles (20-40). The concentration of the RT-PCR products was determined by densitometry. The internal DNA standard and the sample sequence were amplified with the same efficiency over the whole range of amplification cycles. Probably, it is difficult to make general predictions of how large the maximum size of difference between the standard and the cDNA sequence can be before it influences equal amplification efficiency. This must be tested for each specific standard and corresponding native cDNA sequence.

Continuing the procedure described in this report, an RNA internal RT-PCR standard can also be generated in an in vitro transcription reaction with the plasmid DNA sequence as template. Because the entire 3' UTR is included in the standard RNA sequence, the reverse transcription reaction should not be biased towards either the natural or the standard transcript if oligo-dT is used as primer for reverse transcription.

We find this an easy and, moreover, universal method of obtaining an ideal internal standard to be included in competitive RT-PCR analyses for specific quantitative gene expression measurements.

\section{REFERENCES}

1.Diviacco, S., P. Norio, L. Zentilin, S. Menzo, M. Clementi, G. Biamonti, S. Riva, A. Falaschi, and M. Giacca. 1992. A novel procedure for quantitative polymerase chain reaction by coamplification of competitive templates. Gene 122:313-320.

2.Hoegh, A.M., T.V.F. Hviid, B. Christensen, S. Sørensen, R.D. Larsen, S. Smidt-Jensen, J. Bang, and J. Philip. 2001. Zeta-, epsilon-, and gamma-globin mRNA in blood samples and CD71(+) cell fractions from fetuses and from pregnant and nonpregnant women, with 


\section{Benchmarks}

special attention to identification of fetal erythroblasts. Clin. Chem. 47:645-653.

This work was supported by grants from The Pharmacy Foundation of 1991 and Copenhagen Hospital Corporation. Address correspondence to Dr. Thomas Vauvert F. Hviid, Copenhagen University Hospital, Department of Clinical Biochemistry, KB 4111, Rigshospitalet, 9 Blegdamsvej, 2100 Copenhagen $\varnothing$, Denmark. e-mail: hviid@dadlnet.dk

Received 26 April 2001; accepted 5 July 2001.

Anne Mette Hoegh and Thomas Vauvert F. Hviid

Copenhagen University $H: S$ Hvidovre Hospital and H:S Rigshospitalet

Copenhagen, Denmark

For reprints of this or any other article, contact Reprints@BioTechniques.com 